\title{
Vapaa käytäntö ja arvovapaa tutkimus
}

\section{Kommentteja Harvan kommenteihin}

Urpo Harva on edellä tarttunut useihin mieliteemoihinsa, joissa todella riittää pohdittavaa ja keskusteltavaa. Tyydyn tässä pikavastineen tapaan käymään lyhyesti läpi sellaisia "Johdatuksen" kohtia, joiden reunaan vanha opettajani on piirrellyt pukkeja punakynällään. Lukijan osaa helpottaakseni noudatan pääasiallisesti Harvan tekstin etenemisjärjestystä.

\section{Vapaa aikuiskasvatus}

Harva aloittaa Suomen aikuiskasvatuksen historiallisista kehitysvaiheista. Häneltä jää huomaamatta että "Johdatuksessa" kehitystä yritetään tarkastella Euroopan perspektiivistä. Harvan vierastamaa termiä "vapaa aikuiskasvatus" käytän lähinnä käsitteen liberal adult education suomennoksena mutta kuvaan sillä brittiläis-saksalais-pohjoismaisen aikuiskasvatuksen tiettyä yhteisten peruskäsitysten suuntaamaa kehityskautta. Termiä ei pidä irrottaa näistä yhteyksistään. Harvan kaksinapaiselle ajattelutavalle on luonteenomaista, että käsitteellä pitäisi oikeutetuksi tullakseen olla vastakohta. Onko vapaalla sivistystyöllä kiinteästi määrittyvä käsitteellinen vastinparikki? Saksassa on erotettu vapaa ja sidonnainen aikuiskasvatus, mutta molempien määrittely poikkeaa olennaisesti pohjoismaisesta. Englannin perinteisen liberal adult education -käsitteen tunnuspiirteeksi taas on usein määritelty non-vocational, mikä viittaa ammatilliseen aikuiskasvatukseen Harvan kaipaamana "vastakohtana"'. Tosiasiallisesti käsitten liberal adult education ulkopuolelle jää iso joukko muitakin organisoitujen aikuisopintojen tehtävä- ja toimintalohkoja. Kaiken kaikkiaan olen turvautunut termiin vapaa aikuiskasvatus juuri sen takia, että mikään vakiintunut termi, esimerkiksi pohjoismainen "vapaa sivistystyö", ei oikein sovi kansallisilta erityispiirteiltään poikkeavien traditioiden yhteisen perussuuntauksen nimitykseksi ${ }^{1}$.

\section{Tehtäväalan määrittely: käytäntö ja tutkimus}

Edellä sanottu oli asian merkitystä ajatellen pientä alkuverryttelyä: kyseistä termiä ei suinkaan välttämättä tarvita mutta haitanneeko tuon käyttökään rajatussa yhteydessä mitään. Merkityksellisiin peruskysymyksiin kuuluu sen sijaan aikuiskasvatuksen käytännön ja sitä koskevan tutkimuksen ja teorianmuodostuksen tehtäväalan määrittely. Kun 'Johdatuksessa" olen Harvan esittämällä tavalla jakanut käytännön toiminnan eriytyneeseen ja eriytymättömään aikuiskasvatukseen, olen samalla asettunut sille kannalle että käsitteelle on perusteltua antaa sekä suppeampi että laajempi merkitys. Harva ei asetu tällaista jäsentelyä ja käsitelan avartamista vastaan; sen sijaan hän on tullut uusiin ajatuksiin käytäntöä vastaavan oppiaineen kohdealasta (tiedekäsityksensä mukaisesti Harva ilmeisesti mieluiten käyttää käsitteitä aikuiskasvatusoppi ja kansansivistysoppi). Olen tulkinnut Harvan esityksen tässä kohdin niin, että meidän uudet ajatuksemme etenevät samaan suuntaan, mutta että käsityksemme käytännön ja tutkimuksen keskinäisestä suhteesta (kohdealan määrittely) eroavat toisistaan. Yritän hiukan selvittää omaa käsitystäni.

Harva siteeraa tekstiäni, jonka mukaan "varsinaisen" aikuiskasvatuksen kannalta on tärkeätä ottaa huomioon ne kasvatukselliset vaikutukset, joita aikuisiin suuntautuu eriytyneen opintotoiminnan ulkopuolella...' Harva on tulkinnut tämän tarkoittamaani suppeammin, mihin osaltaan on ehkä johtanut se, että lainatun virkkeen välitön jatko on jäänyt huo- 
maamatta: "...ja se informaalinen oppiminen, jota tapahtuu aikuisten toimiessa erilaisissa sosiaalisissa yteisöissä ja vuorovaikutussuhteissa". Informaalinen oppiminen on tarkoitettu käsitteenä laajemmaksi kuin eriytymätön aikuiskasvatus. Tärkeintä kuitenkin on, että huomioon ottaminen ei tässä tarkoita tutkimusta, kuten Harva olettaa. Puhe on käytännön aikuiskasvatustyöstä: keskityttäessä organisoituihin opintoihin on pidettävä mielessä että aikuiset oppivat kaiken aikaa myös niiden ulkopuolella (vrt "Johdatus"' s. 87). Elinikäisen kasvatuksen termein on kysymys horisontaalisesta yhdentämisestä.

Jostakin syystä Harva on vastoin tarkoitustani olettanut myös, että rajoittaisin aikuiskasvatuksen tutkimuksen kohdealan käytännön aikuiskasvatustoimintaan.

"Johdatuksen" luvuista 4-9 pitäisi kyllä käydä aivan läpikäyvästi ilmi, että Harvan tavoin luen aikuiskasvatustutkimuksen problematiikkaan myös ei-kasvatukselliset vaikutukset. Kirjan useissakin kohdissa on nostettu aikuisten arkikokemuksesta oppiminen tutkimusteemana esille ja yritetty osoittaa, että ihmisten elämäntavan suuntauksia kannattaisi tutkia aikuiskasvatuksen näkökulmasta. Omiin tutkimushaaveisiini kuuluu aikuisten elämänkulkuun liittyvien kehittymistehtävien selvittely käyttämällä aineistona suomalaista sanataidetta. En epäile ettei siitä saisi aivan viimeisen pällle aikuiskasvatustieteellistä ${ }^{2}$. Milloin tutkimus siis täyttää aikuiskasvatustieteen kriteerit? "Johdatuksessa"' on väitetty (s. 61) että tutkimus on varsinaisesti aikuiskasvatustieteellistä silloin, kun tavoitteena viime kädessä on saada lisävalaisua aikuisiin kohdistuvan kasvatuksellisen vaikuttamisen mahdollisuuksita (vrt. lehtemme tämänkertaisen pääkirjoitukseen).

Ohimennen todettakoon että Castrénin kokonaiskäsitys vapaan sivistystyön käsitteestä ei käy riittävästi esille kuuluisasta muutamaan virkkeeseen tiivitetystä määritelmästä. Jo määritelmää täydentävästä tekstistä ilmenee että Castrén asettaa käsitteelle myös järjestelmällisen oppimisen ('vakavan opiskelutyön') ja sitä organisoidusti tukevan toiminnan kriteerit ${ }^{3}$.

\section{Tieteen ja tutkijan arvovapaus}

Harva ilmoittaa olevansa ankarasti positivistisen tiedekäsityksen kannalla, jonka mukaan aikuiskasvatustieteenkin on oltava arvovapaata. En yhdy näin jyrkkään käsitykseen mutta Harva tulkitsee oman kannanottoni liian kategorisesti päinvastaiseksi. Tosiasiallisesti otan tekstissäni esille arvovapauden ja arvosidonnaisuuden eri merkityksiä ja totean $\mathrm{mm}$.: ''Kasvatustutkimus on väistämättä arvosidonnaista siinä merkityksessä, että tutkija tekee aina arvovalintoja tiedostipa hän sitä tai ei' (mt. s. 53). Toisaalta yritän tähdentää että kasvatustutkimuksenkin on suhteessaan arvostuksiin täytettävä tieteellisen objektiivisuuden vaatimukset.

Aikuiskasvatuksen perustason oppikirjassa ei vaikeaa tieteenfilosofista kiistakysymystä voi perusteellisesti käsitellä, mutta paljon pitemmälle en nykyisin eväin ole valmis omakohtaista käsitystäni kehittelemäänkään. Yhdyn joka tapauksessa siihen kasvatustieteissä viime vuosikymmeninä vallinneen uuspositivistisen suuntauksen kritiikkiin, jota "Johdatuksessa"' lyhyesti esittelen (mt. s. 52 ja 68-69).

Harvan kanssa olemme yhtä mieltä siitä että filosofisen ajattelun keinoin ja empiirisen tutkimustiedon avulla voidaan selkeyttää ja tarkistaa käytännön aikuiskasvatuksen arvoratkaisujen perusteita. Käsityksemme ovat yhdensuuntaiset myös siinä, että aikuiskasvatuksen tutkijan on tehtävä arvoratkaisuja mutta tutkijan arvostukset eivät saa vääristää totuuden havaitsemista ja tulkintaa. Harva tekee "'kuitenkin jyrkän eron tutkijan ja tieteen välillä', ja tässä en pysty hänen ajattelutapaansa seuraamaan ${ }^{4}$. Viime kädessä Harvalle näyttää riittävän, että tutkija ''ilmaisee selvästi, mikä hänen kirjoituksissaan on puhdasta tiedettä, esim. empiirisen tutkimuksen tuloksia, mikä taas on arvopitoista puhetta". Tarkoittaako tämä, että tutkija saa tutkimusraportissaan ottaa kantaa arvokysymyksiin, kunhan erottaa selvästi kannanottonsa "puhtaista tiedeaineksista"?

Kun Harva myöntää tutkimustehtävien valinnat arvoratkaisuiksi, on syytä huomauttaa että jo näistä on väistämättömiä seurauksia myös sille, mitä tutkimus tuottaa (en tarkoita poikkeanista tieteellisen objektiivisuuden vaatimuksista). Selvimmin tämä näkyy tiedeyhteisön jatkuvan työn suuntautumisessa ja tieteelIisen tiedon koostumisessa. En jatka pidemmälle. Toistan vain sen mihin omassa esityksessäni päädyin: tutkimuksen omin tapa auttaa käytäntöä arvoratkaisuissa on selkeyttää tiedollisesti ja käsitteellisesti niiden perusteltavuutta (mt. s. 53). 


\section{Aikuiskasvatus sosialisaationa}

Harva ei pidä kasvatustieteiden luokittamista yhteiskuntatieteisiin riittävästi perusteltuna. Tarkastellaanpa hiukan, mitä hän tässä yhteydessä kirjoittaa kasvatuksesta sosialisaationa. Harva siteeraa ensin väitettäni, että aikuiskasvatus on perusluonteeltaan aikuisuudessa jatkuvaa sosialisaatiota. Kun hän sitten esittää omia käsityksiään, syntyy vaikutelma että ne on tarkoitettu kritiikiksi "Johdatuksessa" esitetylle. Kun Harva taas kerran torjuu organismiteorian, saattaisi jopa päätellä että esittämäni käsitykset hänen mukaansa palautuisivat oletukseen yhteiskunnasta ainoana tosiolevaisena ${ }^{5}$. Tosiasiallisesti Harvan sosialisaation käsitteelle antama merkityssisältö poikkeaa siinä määrin esittämästäni, että ajatuskehikkojamme on vaikea suhteuttaa toisiinsa.

Oma käsitykseni sosiaalistamisesta pohjautuu perusväitteeseen että ihmisestä tulee ihminen vain yhteisössä. Sosiaalistumisprosessiin kuuluvat kaikki ne sosiaalisen yhteisön vaikutukset, jotka karsivat, suuntaavat ja muokkaavat yksilön kehittymispotentiaaleja. Persoonallisuus kehittyy sosiaalisessa oppimisprosessissa, jossa aktiivisesti ympäristöönsä orientoituva ja yhteisössä toimiva yksilö pyrkii käyttämään hyväkseen ympäristön tarjoamia mahdollisuuksia sekä hallitsemaan psyykkisesti sen paineita ja vaatimuksia. Yhteisön tietoinen pyrkimys vaikuttaa yksilön kehittymiseen on kasvatusta eli tietoista sosiaalistamista.

Omaksumani sosialisaation käsite määrittelee siten vain kasvatuksen sosiaalisen, kulttuurisesti välittyvän perusluonteen; kasvatuksen päämäärät voivat vaihdella suurestikin eri yhteisöissä ja muuttua historiallisen muutoksen mukana. Harva sen sijaan kytkee sosialisaation käsitteen kasvatuksen päämäärasuuntauksiin. Personalisaatio ja sosialisaatio ovat saman formaalisen päämäärädimension vastakkaisia suuntia. Sosialisaatio on yhteiskuntaan liittämistä ja mitä enemmän se painottuu kasvatuksen päämääränä, sitä vähemmälle jää personalisaatio, yksilön ainutkertaisuuden huomioon ottaminen. Sosialisaation käsite saa tällä tavoin suppeasti yhteiskuntaan sopeuttamisen merkityksen ja näyttää enemmän tai vähemmän kiinteästi pohjautuvan yhteiskunnan ja yksilön intressien vastakkainasetteluun (Systemaattinen kasvatustiede s. 188-189). Tämäntapainen kahtiajako on ollut suomalaisessa pedagogiikassa yleinen ja monesti sosiali- saatio on siinä määritelty ahtaamminkin kuin Harva tekee ${ }^{6}$. Toisaalta Harvan sosialisaatiokäsitystä määrää hänen erityislaatuinen yksilö versus yhteiskunta-dualisminsa?

Kasvatus ei ole Harvan ajattelutavan mukaan pelkästään sosialisaatiota, koska ihminen ei ole vain sosiaalinen olento. Kun kasvatus käsitetään esittämälläni tavalla kokonaisuudessaan sosiaalistamiseksi, näin ei kielletä tai sivuuteta ihmisen ainutkertaista yksilöllisyyttä. Yksilön ainutlaatuisuuden huomioon ottaminen ja hänen itsetajuisuutensa herättäminen kasvatuksen tehtävänä (Systemaattinen kasvatustiede s. 158-160) ei muuta miksikään kasvatuksen sosiaalista, kulttuurisesti välittynyttä perusluonnetta. Kasvatus pysyy sosialisaationa, vaikka kelpo kansalainen painottuu sen päämääränä eri kulttuureissa ja eri aikoina eri tavoin.

Edellä sanottu ei tarkoita, ettei yksilöllisen ainutkertaisuuden ja sosiaalisen suhde persoonallisuuden kehittymisprosessissa olisi kasvatuksenkin kannalta tärkeä ja vaikea ongelma. Kehityspsykologisesti minätietoisuuden herääminen edellyttää toisen tiedostamista: "sinä on vanhempi kuin minä". Lapsi voi tiedostaa psyykkisen erillisyytensä vain suhteessa sosiaaliseen ympäristöön. Siitä, miten minän autonomisoituminen tapahtuu, on kehitelty erilaisia psykologisia teorioita. Joka tapauksessa yksilöllinen ja sosiaalinen kietoutuvat persoonallisuuden muovautumisessa kiinteästi toisiinsa. Antti Eskola käyttää yksinkertaisena esimerkkinä yksilön puhuntaa, joka on persoonallista ja ainutkertaista, vaikka hänen käyttämänsä kieli on kollektiivinen tuote, jonka kehittyminen on alkanut jo aikoja ennen kyseisen yksilön syntymää ${ }^{8}$.

Harvan sosialisaatiokäsityksestä seuraa, että sosiaalistamisen merkitys kasvatuksessa vähenee yksilönkehityksen edetessä; vähäisin sen osuus on aikuiskasvatuksessa, joka on ytimeltään itsekasvatusta. "Johdatuksessa" minulla oli ilo viitata J. A. Hollon, vanhaan hyvään individualistiin, todetessani että sama kasvuprosessi, joka yksilön kannalta on omaehtoista kasvamista, on sosiaalisesta näkökulmasta kasvatusta. Itsekasvatuskin tapahtuu aina kasvatuksellisten vaikutusten, intentionaalisten ja tietoisesti tarkoittamattomien, alaisena (mt. s. 20). Harva luonnehtii aikuiskasvatusta itsensä todellistamiseksi. Oman sosialisaatiokäsitykseni mukaan yksilön itsensä todellistaminen ei erillisty sosiaalistumisesta, vielä vähemmän on sille jotenkin vastakkaista. Aikuisen itsekasvatus on sen mukaan jatkuvaa sosiaalistumista, jota parhaimmillaan (huomaa: 
arvostus) ohjaa kehittynyt itsehallinta mutta myös sellainen kehittynyt sosiaalinen tietoisuus, jota Allport nimitti minuuden laajentumiseksi (extension of the self).

\section{Kasvatustieteiden asema tiedejärjestelmässä}

Yhdyn Harvaan siinä että ettei kysymys kasvatustieteiden paikasta tiedejärjestelmässä ole kovin tärkeä. Kuten 'Johdatuksessa'" totean, "tieteiden ryhmittelylle on vaikea, ellei mahdoton, löytää yksiselitteisesti toimivia kriteerejä eikä kaikkia yksittäisiä tieteitä minkään luokituksen mukaan voida sijoittaa riidattomasti vain yhden pääluokan yhteen alaluokkaan" (mt. s. 49). Niin aikuiskasvatuksen kuin yleensäkin kasvatuksen tutkimus ja teorianmuodostus on varsinkin nykyisellään leimallisesti monitieteistä. Kun tuollaista luokitusta sekä käytännön syistä että tiedeperustan selvittelemiseksi harjoitetaan ja kasvatustieteet on sijoitettava yhteen tiettyyn luokkaan, silloin ne on perustellumpaa - nykyisessä kehitysvaiheessaan - sijoittaa yhteiskuntatieteisiin kuin esimerkiksi humanistisiin tieteisiin, joihin niillä myös on perinteisesti läheiset yhteydet. Perustelu on Harvan siteeraama: tutkimuskohteen eli kasvatuskäytännön yhteiskunnallinen luonne.

Harva pitää hyvänä että suomalaisissa yliopistoissa on yhteiskuntatieteellisen ja humanistisen tiedekunnan rinnalla kasvatustieteellinen tiedekunta. Valitettavasti niissä ei ole edustettuina Harvan luettelemia perustieteitä. Siksi ne ovatkin jonkinlaisia tynkäfakulteetteja, joiden perustaminen oli mielestäni erehdys.

\section{Humanistinen arvofilosofia}

Sananvaihdostamme saattaa syntyä käsitys, että olemme Harvan kanssa aikuiskasvatuksen teoreettisista perusteista hyvinkin totaalisesti eri linjoilla. "Johdatuksestakin" tulee kyllä näkyviin, ettei näin sentään ole laita. Yksi peruskysymys, jossa olen vahvasti Harvan kannalla, on käsitys aikuiskasvatuksen arvofilosofian humanistisesta perinteestä. Harvan väite, että olisin maininnut humanismin vain yhdessä kohdin, ei tarkasti laskien pidä paikkaansa. Totta kuitenkin on, että määräajan puserruksessa jouduin jättämään kirjasta luvun, jossa oli tarkoitus käsitellä aikuiskasvatuksen päämääriä ja tavoitteiden asettelua.

Jos olisin kirjoittanut humanismista enemmän, Harvalle olisi saattanut kyllä tulla lisää kriittisten kommenttien aihetta. Vierastan Harvan humanismi-käsityksen korostunutta individualismia ja liityn siihen suuntaukseen, jota Harva on eräässä äskeisessä esseessään nimittänyt sosiaaliseksi humanismiksi. Puoliksi tosissani ihmettelen vielä, mikä esityksessäni sivistyksellisestä tasavertaisuudesta meni vikaan, kun Harvalla ei tällä kertaa ollut sitä vastaan mitään huomauttamista.

Harvan kirjoituksessa on useita muitakin teemoja, jotka ansaitsisivat huomiota. Toivottavasti joku muukin jatkaaa keskustelua.

\section{Viitteet}

${ }^{1}$ Käsittelen asiaa hiukan enemmän tutkimuksessani "Sivistysjärjestöjen tehtävänkuvan muuttuminen" (ilmestyy Tampereen yliopiston aikuis- ja nuorisokasvatuksen laitoksen julkaisusarjassa).

Harva on muuten itsekin joskus turvautunut termiin vapaa aikuiskasvatus. Seuraava sitaatti on artikkelista "Mitä on aikuiskoulutus", Aamulehti 10.3.1971:

"Sananmukaisesti aikuiskasvatuksella tarkoitetaan kaikkea aikuisiin kohdistuvaa kasvatusta. Tavallisesti siinä erotetaan ammatillinen (engl. vocational adult education) ja vapaa aikuiskasvatus (liberal adult education). Jälkimmäisessä on ytimenä pyrkimys yleissivistykseen ja kansalaiskasvatukseen. Ammatillista ja vapaata aikuiskasvatusta ei voida erottaa jyrkästi toisistaan."

${ }^{2}$ Harva on harjoittanut kiintoisalla tavalla romaanianalyysia tutkielmassaan "Työväen sivistys"' (Vapaa kansansivistystyö IX. Otava 1961).

${ }^{3}$ Myös Castrénin käsitteenmäärittelyä olen selvittänyt vähän perusteellisemmin viitteessä 1 mainitussa työssäni.

${ }^{4}$ Tero Autio on Harvan juhlakirjassa huomauttanut, ettei Harvan positivistiseen tieteenkäsitykseen sisälly tavanomaista skientismia; empiirisen kasvatustieteen tutkiman todellisuuden ulkopuolelle jää kasvatuksen ideaalimaailma, jonka tutkiminen on kasvatusfilosofian tehtävä. Autio, Kasvatuksesta ja sen tutkimuksesta. Teoksessa Manni \& Tuomisto (toim.). Humanistin teemojen tuntumassa. Tampere 1985.

Omasta puolestani suhtaudun hyvin epäillen Harvan tapaan erottaa empiirinen ja filosofinen tutkimus toisistaan.

${ }^{5}$ Harvan taistelu organismisteoriaa vastaan, joka hänen mukaansa olettaa yhteiskunnan tajuiseksi olennoksi solumaisine jäsenineen, tuntuu vähän turhalta: missä ovat puolustajat? Tuskinpa myöskään Durkheim hyväksyisi Harvan mutkatonta tulkintaa sosiaalisen autonomisuuden postulaatistaan. Sillä ei kuitenkaan tässä yhteydessä ole merkitystä, koska omat viittaukseni Durkheimiin rajoittuivat hänen tapaansa ilmaista se tosiasia, että kasvatus on yhteiskunnan välttämätön perustehtävä ja kasvatustoiminta on kiinteässä yhteydessä yhteiskunnan rakenteisiin. 
${ }^{6}$ Esimerkiksi Lahdes, Peruskoulun uusi opetusoppi (Otava 1977) s. 63-64. Lahdes näyttää mm. olettavan että yksilön kriittisyys vallitsevia arvoja kohtaan ei tavoitteena kuuluisi sosialisaation piriin. Lahdes käyttää personalisaation sijasta termiä individualisaatio. Terminvaihdos on perusteltu (par. individuaatio), mutta käsitteellistä kahtiajakoa se ei tee yhtään onnistuneemmaksi.

${ }^{7}$ Autio selittää parhain päin myös Harvan "'metodista dualismia" viitteessä 4 mainitussa esseessään (s. 210). Kyseessä ei Aution mukaan ole niinkään to- dellisuuden luonteen lopullinen, mustavalkea kuvaus kuin omaperäinen dialektisen metodin muoto. Minusta kaksijakoiseen jäsentämistapaan nimenomaan liittyy taipumus luokittaa asioita jokotai-periaatteella.

${ }^{8}$ Eskola, Vuorovaikutus, muutos, merkitys (Tammi 1982), s. 106. Eskolan teos tarjoaa olennaisen tärkeää perustaa myös aikuiskasvatuksen sosiaalistamiskäsitykselle selvittämällä yhteiskunnan perusrakenteiden ja niiden historiallisen kehityksen merkitystä persoonallisuuden ja ihmissuhdemallien muovautumiselle. 